\title{
Wykształcenie facjalne i korelacja profili warstw krośnieńskich z odsłonięć i otworów wiertniczych (fałd Gorlic, jednostka śląska, Karpaty)
}

\author{
Facies development and profile correlation of the Krosno Beds from outcrops and \\ boreholes (Gorlice Fold, Silesian Unit, Outer Carpathians)
}

\author{
Arkadiusz Drozd, Piotr Dziadzio, Marek Stadtmüller \\ Instytut Nafty i Gazu - Państwowy Instytut Badawczy
}

\begin{abstract}
STRESZCZENIE: Celem niniejszej pracy jest zaprezentowanie szczegółowej dokumentacji facji warstw krośnieńskich południowego skrzydła fałdu Gorlic, odsłaniających się w korycie rzeki Sękówka, na odcinku Gorlice-Sękowa. Na podstawie prac terenowych wykonano szczegółowy profil litologiczny uwzględniający cechy sedymentologiczne, o łącznej rzeczywistej miąższości $1415 \mathrm{~m}$. W obrębie warstw krośnieńskich wydzielono i opisano 11 facji osadowych (I-XI), dla których na tym etapie badań nie interpretowane jest środowisko depozycji. Wydzielono i opisano 3 rodzaje osadów heterolitowych. Rozpoznano i udokumentowano również 15 struktur sedymentacyjnych, które zostaną wykorzystane do dalszej interpretacji warstw krośnieńskich w zakresie ich genezy. Kolejnym elementem zrealizowanym w pracy jest korelacja terenowego profilu litologicznego z zapisem i interpretacją profilowań geofizyki wiertniczej (wystandaryzowanych do jednostek fizycznych psAPI, petrofizyczny trójskładnikowy model matrycy) z otworów Gorlice-12 i Gorlice-13, przewiercających bezpośrednio badany interwał litostratygraficzny. Wszystkie trzy profile zostały zestawione i odniesione do granicy stropu warstw menilitowych (poziom wyrównania), która jest bardzo dobrze widoczna, zarówno w terenie, jak i w zapisie krzywych geofizyki otworowej. Przyjęta metodyka pozwoliła na wyznaczenie 5 charakterystycznych granic: G1, G2, G3, G4, G5. Wyznaczone one zostały w spągu piaskowców masywnych przypisanych facji VIII (granice G1, G2, G4, G5) i piaskowców słabo zwięzłych - facja IX (granica G3). Dodatkowo ustalonych zostało 5 linii pomocniczych (P1, P2, P3, P4, P5) na podstawie podobienstwa zapisu profilowania gamma. Wykonany profil terenowy został porównany z jego archiwalnym opisem, czego efektem jest wykazanie różnic w rzeczywistej miąższości, oraz stopniem zmienności litologicznej. Przeprowadzone badania oraz zastosowana metodyka mogą stanowić podstawę do weryfikacji dotychczasowego stanu wiedzy na temat warstw krośnieńskich na szerszym obszarze badań, gdzie występują otwory wiertnicze, jak i profile terenowe. Mogą być one wykorzystywane do regionalnych interpretacji zmienności facjalnej i środowisk depozycji.
\end{abstract}

Słowa kluczowe: warstwy krośnieńskie, facje, korelacja danych, fałd Gorlic.

ABSTRACT: The main objective of this paper is to present documentation of the Krosno Beds facies in the southern limb of the Gorlice Fold, exposed in the Sękówka river bed, on the Gorlice-Sękowa section. On the basis of field work, a detailed lithological profile was compiled, taking into account sedimentary structures. The total true thickness of the profile is $1415 \mathrm{~m}$. Eleven sedimentary facies (I-XI) are described, for which the depositional environment has not been interpreted at this stage of the research. Three types of heterolithic sediments were described. Fifteen sedimentary structures have been identified and documented, which will be used for future interpretation of the Krosno Beds sedimentary environment. Another element conducted in the study is the correlation of the lithological field profile with the well logs interpretation (standardized to psAPI physical units, evaluation of the petrophysical model) from the Gorlice-12 and Gorlice-13 boreholes directly drilling through the studied lithostratigraphic interval. All three profiles have been correlated with reference to the datum defined by the upper boundary of the Menilite Beds which is clearly identifiable both in the field and in the well logs. The adopted methodology made it possible to define 5 correlation boundaries (G1, G2, G3, G4, G5), based on the massive sandstones - facies VIII (boundaries G1, G2, G4, G5) and low-compact sandstones - facies IX (boundary G3). In addition, 5 auxiliary lines have been marked (P1, P2, P3, P4, P5) based on the similarities of the gamma well logs. The field profile was compared with its archival description, the results of which shows differences in the true thickness and the degree of lithological variability. The conducted research and the applied methodology may provide the basis for verifying the current state of knowledge on the Krosno Beds in a regional border area, where there are boreholes and field profile. They can be used for regional interpretations of facies variability and deposition environments.

Key words: Krosno Beds, facies, data correlation, Gorlice Fold.

Autor do korespondencji: A. Drozd, e-mail: arkadiusz.drozd@inig.pl

Artykuł nadesłano do Redakcji 04.04.2019 r. Zatwierdzono do druku 05.11.2019 r. 


\section{Obszar badań i zarys litostratygraficzny}

Obszar badań znajduje się w obrębie południowej części jednostki śląskiej, kontaktując z północnym brzegiem płaszczowiny magurskiej. Analizowany profil warstw krośnieńskich odsłania się w korycie rzeki Sękówka, na odcinku pomiędzy Gorlicami a Sękową (rys. 1).

Dominującym elementem strukturalnym obszaru badań jest fałd Gorlic, który w przeszłości był szeroko badany i analizowany ze względu na występujące w jego obrębie złoża ropy naftowej i gazu ziemnego. Spośród wielu prac analitycznych przytoczyć można np. oparte na pracach wcześniejszych autorów prace Kozikowskiego (1956), Kozikowskiego i Jednorowskiej (1957), Konarskiego (1980), opisujące budowę geologiczną fałdu. W strefie przypowierzchniowej fałd ten ma kształt eliptyczny, długości 13 km i maksymalnej szerokości 5 km (dolina Ropy, por. Konarski, 1980). Przebieg osi fałdu wykazuje trend równoleżnikowy, a jego maksimum wynurzenia przypada na rejon Gorlice-Kobylanka-Kryg, gdzie w jądrze występują piaskowce warstw istebniańskich górnych. W kierunkach na wschód i na zachód obserwuje się stopniowe zanurzanie jego osi w obrębie coraz to młodszych osadów paleogenu (Szymakowska, 1979). Fałd Gorlic dzieli się poprzecznie na blok wschodni i zachodni, z linią podziału stanowiącą poprzeczną dyslokację strefy Ropy (Konarski, 1980).

W budowie geologicznej rejonu Gorlic główną rolę odgrywają ogniwa litostratygraficzne warstw istebniańskich, tzw. pstrego eocenu, warstw menilitowych, krośnieńskich oraz utwory zawierające w swoim składzie fragmenty ww. tkwiące w mioceńskim matrix (Jankowski, 1997, 2007). Cechą charakterystyczną osadów budujących profil fałdu Gorlic jest ich wybitnie piaskowcowy charakter, począwszy od górnych warstw istebniańskich po dolne warstwy krośnieńskie. Innym istotnym faktem jest brak poziomu rogowcowego w spągu serii menilitowej, który zastąpiony jest kilkumetrowej miąższości serią margli krzemionkowych (Szymakowska, 1979; Dziadzio et al., 2016).

Analizowane w pracy warstwy krośnieńskie rejonu Gorlic były przedmiotem bezpośrednich badań prowadzonych przez

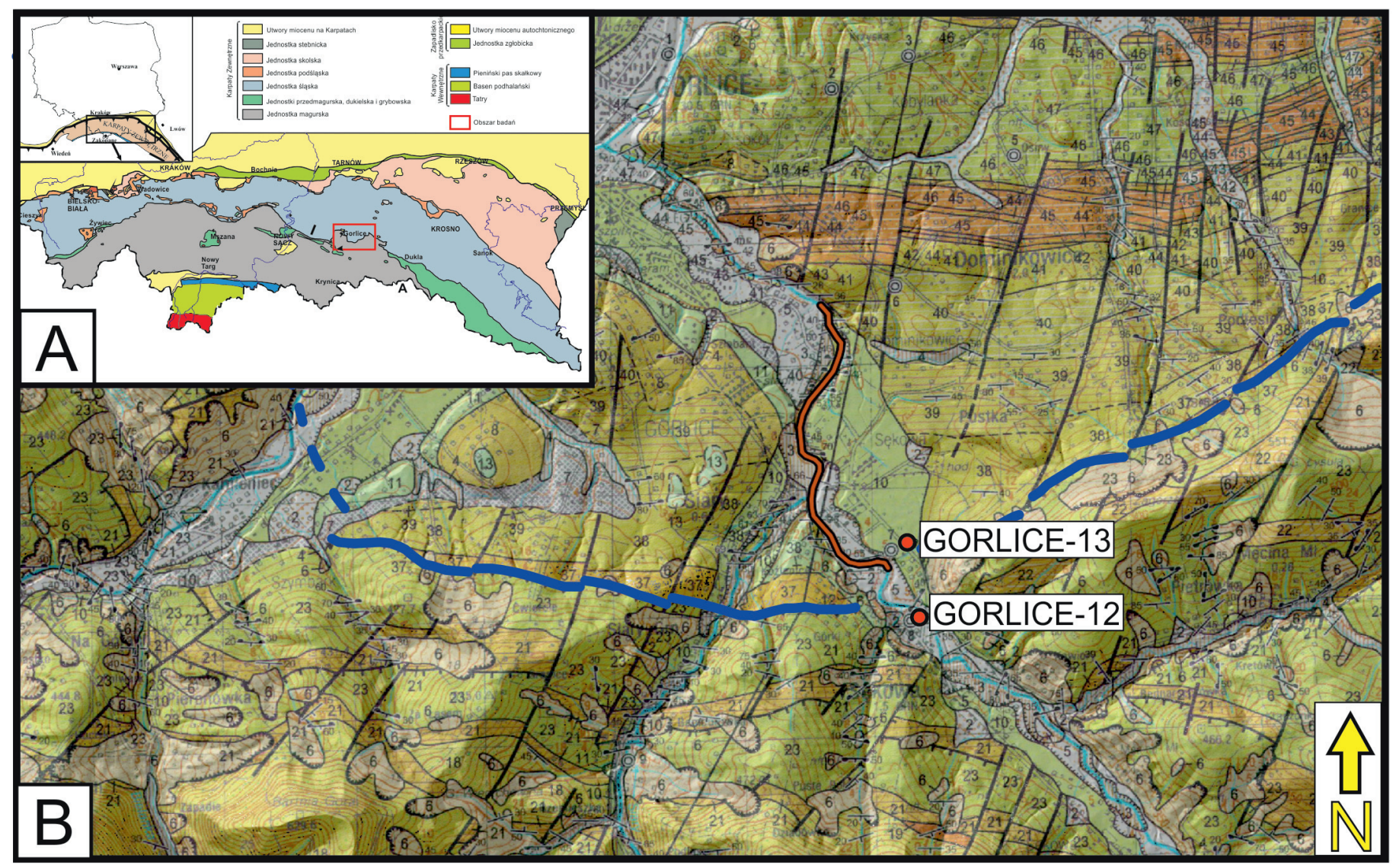

Rys. 1. (A) Lokalizacja rejonu badań na zmodyfikowanej, uproszczonej mapie geologicznej Karpat zewnętrznych (na podstawie Poprawa i Nemčok, 1989); (B) Lokalizacja profilu i wykorzystanych otworów wiertniczych na tle SMGP arkusz 1037 Gorlice (Kopciowski et al., 2014) oraz cyfrowego modelu terenu LIDAR (https://www.geoportal.gov.pl). Linia czerwona - przebieg profilowanego interwału warstw krośnieńskich wzdłuż rzeki Sękówka; linia niebieska - nasunięcie jednostki magurskiej na jednostkę śląską

Fig. 1. Location of the study area on the modified, simplified geological map of the Polish part of the Outer Carpathians (based on Poprawa and Nemčok, 1989); (B). Location of the lithological profile and boreholes on the Detailed Geological Map of Poland - 1037 Gorlice (Kopciowski et al., 2014) and on the digital LIDAR terrain model (https://www.geoportal.gov.pl). The red line - field profile of the Krosno strata along the Sękówka river; blue line - thrust of the Magura Unit on the Silesian Unit 
Szymakowską (1959, 1979), Świdzińskiego (1973a, b) lub też elementem analiz o szerszym zasięgu, prowadzonych np. przez Juchę i Kotlarczyka (1959) czy Wdowiarza (1985).

Według dotychczasowych wyników badań warstwy krośnieńskie w strefie Gorlic mają trójdzielną budowę. Są dzielone na: dolne, środkowe i górne (Szymakowska, 1959, 1979). Kryteriami do tego podziału były różnice facjalne i cechy litologiczne. Poszczególne ogniwa z różnych profili nie odpowiadają sobie ani pod względem miąższości, ani podobnego wykształcenia facjalnego (z wyjątkiem dolnego ogniwa) (Szymakowska, 1959, 1979).

Kontakt pomiędzy serią menilitową a krośnieńską w zależności od profilu (w obszarze fałdu Gorlic) jest ostry lub też przejściowy, co charakteryzuje się naprzemianległym występowaniem, na przestrzeni około 20 do 50 metrów, glaukonitowych piaskowców magdaleńskich i mikowych wapnistych piaskowców krośnieńskich oraz cienkich wkładek łupków brunatnych (Szymakowska, 1959). Dziadzio (2015) opisał kontakt warstw menilitowych z krośnieńskimi jako granicę o charakterze osuwiskowym, zdominowanym przez czarne łupki typu menilitowego oraz przewarstwienia piaskowców typu magdaleńskiego i krośnieńskiego.

Jak podaje Szymakowska, w profilach, gdzie granica jest ostra, seria przejściowa ogranicza się do występowania wkładek łupków brunatnych (typu menilitowego) w obrębie piaskowców krośnieńskich dolnych. Piaskowce te są wapniste, mikowe, frakcji gruboziarnistej w dole profilu, przechodzące ku górze w drobnoziarniste piaskowce rozdzielane wkładkami szarych łupków. Warstwy krośnieńskie środkowe budują występujące naprzemianlegle w różnych proporcjach twarde laminowane piaskowce płytowe, łupki popielate oraz kompleksy łupkowo-piaskowcowe, z przewagą piaskowców, jak i mułowców. Łączna miąższość tego pakietu wynosi $550 \mathrm{~m}$. Warstwy krośnieńskie górne budują głównie facje łupkowe, z nielicznymi wkładkami piaskowców cienkoławicowych. W stropowej części odsłaniającego się w rzece Sękówka profilu występują cienkie wkładki łupków/wapieni jasielskich (Świdziński, 1973b).

\section{Metody badań}

Podstawą niniejszej pracy są wyniki dokumentacji facji (w rozumieniu: Walker i James, 1992) warstw krośnieńskich odsłaniających się w korycie rzeki Sękówka na odcinku $2800 \mathrm{~m}$ pomiędzy Gorlicami a Sękową. Kolejnym elementem pracy jest korelacja krzywych geofizycznych z otworów wiertniczych Gorlice-12 i Gorlice-13 (według metodyki: Pirson, 1977), przewiercających ten profil, oraz próba jej dopasowania do profilu litologicznego, głównie na podstawie zmienności facjalnej i trendu zmian w zapiaszczeniu.

\section{Analiza litofacjalna}

W ramach opisu sedymentologicznego rejestrowano: litologię, grubość ziarna, cechy stropowe i spągowe, wewnętrzne struktury sedymentacyjne, kolor, miąższość rzeczywistą warstw, miąższość zestawów warstw. W opisywanych interwałach, gdzie ze względów praktycznych (znaczna miąższość pakietu zbudowanego z cienkich warstw) bądź braku możliwości szczegółowego opisu (np. skały odsłaniające się tylko pod powierzchnią wody) wyróżniane były pakiety o heterolitowym charakterze. Opis sporządzano na postawie makroskopowych obserwacji, oceniając procentowy udział głównych składników budujących profilowany interwał (piaskowiec, mułowiec/iłowiec). Wydzielono i opisano 3 rodzaje osadów heterolitowych (rys. 2A - kolumna „Litologia”):

- heterolit A - piaskowcowy - charakteryzujący się obecnością ponad $70 \%$ piaskowca w stosunku do mułowców/ iłowców (max. 30\%);

- heterolit B - piaskowcowo-mułowy - charakteryzujący się obecnością podobnych proporcji piaskowca $(50 \%)$ do mulowca/iłowca (50\%);

- heterolit C - mułowcowo/iłowcowo-piaskowcowy, charakteryzujący się przewagą mułowca/iłowca (od 70\%) nad piaskowcem (max. 30\%).

Oprócz wykonania opisu facjalnego skał mierzono też: kierunki paleotransportu na spągowych powierzchniach piaskowców oraz kąt zapadania warstw (mierzony zawsze prostopadle do ich rozciągłości, przy uwzględnieniu zmiennego przebiegu koryta rzeki), który był parametrem kluczowym w obliczaniu rzeczywistej miąższości warstw. Miąższość rzeczywista opisanego profilu, obliczana z iloczynu cosinusa kąta zapadania i miąższości pozornej, wynosi $1415 \mathrm{~m}$ (rys. 2A).

W celu udokumentowania zaobserwowanych i opisanych w pracy litofacji i struktur sedymentacyjnych sporządzono obszerną dokumentację fotograficzną. Posłużyła ona do wykonania 4 tablic pokazujących i opisujących wydzielone facje (tablice 1-3) oraz najistotniejsze struktury sedymentacyjne (tablica 4).

Całość prac terenowych rejestrowana była w formie cyfrowej, przy wykorzystaniu specjalistycznego oprogramowania LithoHero (Lithohero.com), pozwalającego na zapis cyfrowy wszystkich makroskopowych cech warstw krośnieńskich. Umożliwiło to wykonanie ciągłego profilu sedymentologicznego w czasie prac w terenie (rys. 2A).

\section{Analiza profilowań geofizyki wiertniczej}

Dostarczone dane z dwóch odwiertów: Gorlice-12 i Gorlice-13 zostały poddane analizie jakościowej i ilościowej na podstawie danych laboratoryjnych: porowatości efektywnej, gęstości objętościowej, przepuszczalności i zawartości węglanów (sprawozdania otworowe G-12 i G-13 (Zychowicz, 1980; 
Zwierzyńska, 1984). Wykonano też standaryzację zapisu krzywych gamma jednostek fizycznych psAPI (pseudowartości) oraz interpretację modelu petrofizycznego trójskładnikowej matrycy (zailenie, węglany, kwarc).

Celem oszacowania przybliżonej rzeczywistej miąższości przewierconych warstw wykonano analizę strukturalną na podstawie danych z rdzeni wiertniczych (kąt upadu), przyjmując uproszczone założenie, że odwiert jest pionowy oraz azymutu kąta upadu jest do niego prostopadły.

Średni kąt upadu strukturalnego w otworze (dane z opisu rdzeni wiertniczych) o wartość $\alpha=60^{\circ}$ został użyty do obliczenia skorygowanej miąższości przewierconych warstw według wzoru na TVD $($ TVD $[\mathrm{m}]=\operatorname{MD}[\mathrm{m}] \times \cos \alpha)$.

\section{Facje warstw krośnieńskich}

Na podstawie cech makroskopowych wyróżniono w terenie 11 najczęściej obserwowanych facji osadowych. Zostały opisane i udokumentowane zdjęciami w kolejności od facji o najdrobniejszym ziarnie po facje najbardziej gruboziarniste, z uwzględnieniem facji węglanowych (tablice 1-3). Zidentyfikowano i opisano szereg struktur sedymentacyjnych - śródławicowych: laminacja równoległa (tablice 1A, 2B, 3B), laminacja riplemarkowa prądowa (tablice 1D, 2A, 4D1, 4E1), laminacja riplemarkowa wstępująca (tablica 4E1), laminacja konwolutna, warstwowanie przekątne w dużej skali (tablice 4C, 4C1), warstwowanie przekątne rynnowe; spągowych: hieroglify uderzeniowe, wleczeniowe, podwójne ślady wleczeniowe, hieroglify prądowe (tablica 4E), struktury obciążeniowe; stropowych: riplemarki prądowe (tablica 4D), laminacja sinusoidalna (tablica 4D), ripplemarki symetryczne (tablica 4A), warstwowanie konwolutne, kopułowe warstwowanie przekątne (tablice 4B, 4B1).

Tablica 4 przedstawia struktury diagnostyczne najbardziej istotne z punktu widzenia ich możliwego wykorzystania do interpretacji środowisk sedymentacji.

\section{Korelacja profilu litologicznego i danych otworowych}

W oparciu o terenowy profil litologiczny uwzględniający cechy sedymentologiczne oraz profile geofizyki wiertniczej z otworów Gorlice-12 i -13, została wykonana korelacja w obrębie warstw krośnieńskich.

Zarówno profil terenowy, jak i zapis geofizyki wiertniczej zostały sprowadzone do miąższości rzeczywistej (patrz wyżej: Metody badań). Miąższość rzeczywista warstw krośnieńskich opisanych w korycie rzeki Sękówka wynosi 1415 m i jest to wartość zbliżona do wartości obliczonych w otworach:
Gorlice-13 - 1500 m i Gorlice-12 - 1800 m. Brak dokładnego dopasowania może wynikać ze zjawisk tektonicznych oraz z przyjętych uproszczonych założeń w wypadku przeliczania wartości TVD dla otworów. Należy zauważyć, że miąższość warstw krośnieńskich opisanych w terenie jest niepełna, ponieważ górna część profilu ograniczona jest nasunięciem jednostki magurskiej (rys. 1).

Korelację międzyotworową wykonano na podstawie profilowania gamma po standaryzacji do jednostek fizycznych (psAPI) oraz opierając się na kolumnie „Litologia” (rys. 2B, C), będącej interpretacją modelu petrofizycznego trójskładnikowej matrycy (zailenie, węglany, kwarc).

Terenowy profil warstw krośnieńskich (rys. 2A) został skorelowany z otworami na podstawie litologii i krzywej uziarnienia.

Opisany terenowy profil litologiczny lepiej koreluje się z otworem Gorlice-13 niż Gorlice-12. Oprócz ich zbliżonej miąższości rzeczywistej - podobieństwo wykazują też wyinterpretowane profile: litologiczny i litofacjalny z tego otworu (G-13) (por. rozdział: Metody badań) (rys. 2B).

W celu wykonania korelacji wszystkie 3 profile zostały razem zestawione i odniesione do granicy stropu warstw menilitowych (poziom wyrównania), która jest bardzo dobrze widoczna w terenie, jak i w zapisie krzywych geofizyki otworowej.

Przyjęta metodyka pozwoliła na wyznaczenie 5 charakterystycznych granic, numerowanych kolejno skrótami: G1, G2, G3, G4, G5. Zostały one wyznaczone w spągu piaskowców masywnych przypisanych facji VIII (granice 1, 2, 4, 5) i piaskowców słabo zwięzłych tworzących fację IX (granica 3). Dodatkowo wyznaczonych zostało 5 korelacyjnych linii pomocniczych (P1, P2, P3, P4, P5) (rys. 2).

Granica 1 (G1) jest granicą związaną z końcem sedymentacji serii menilitowej. W jej stropie widoczne są struktury osuwiskowe, ze zdeformowanymi fragmentami piaskowców typu krośnieńskiego. Powyżej zalega pakiet piaskowców krośnieńskich przypisanych facji VIII, o różnej frakcji, od średnio- do gruboziarnistej. Powyżej tej granicy występuje cykliczność tego typu piaskowców (z warstwowaniem konwolutnym, laminacją riplemarkową i równoległą, strukturami pogrązowymi oraz kopułowym warstwowaniem przekątnym). W zapisie geofizyki otworowej piaskowce wykazują kształt blokowy lub lekko dzwonowaty (rys. 2B, C).

Granica 2 (G2) podobnie jak granica 1 została wyznaczona w spągu piaskowców facji VIII. W profilu sedymentologicznym w spągu tych piaskowców, przy założeniu prawidłowej korelacji, występują wielkoskalowe warstwowania przekątne (rynnowe) oraz klasty ilaste (tablice 4C, C1).

Granica 3 (G3) wyznaczona została w spągu piaskowców przypisanych facji IX - piaskowców masywnych oraz warstwowanych przekątnie w dużej skali, z klastami marglistymi, podkreślającymi laminację. Powyżej występują piaskowce 
TABLICA 1

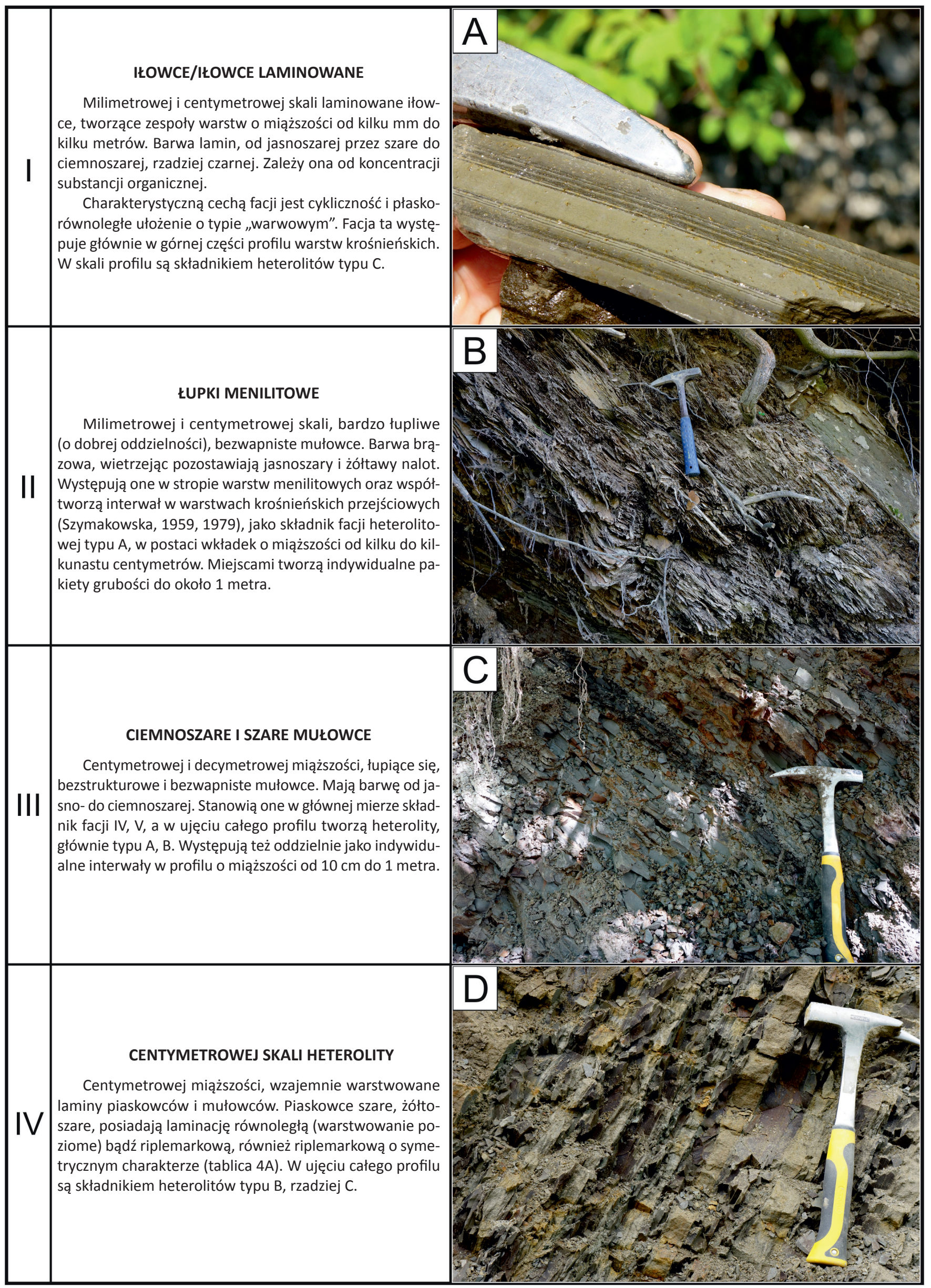


TABLICA 2

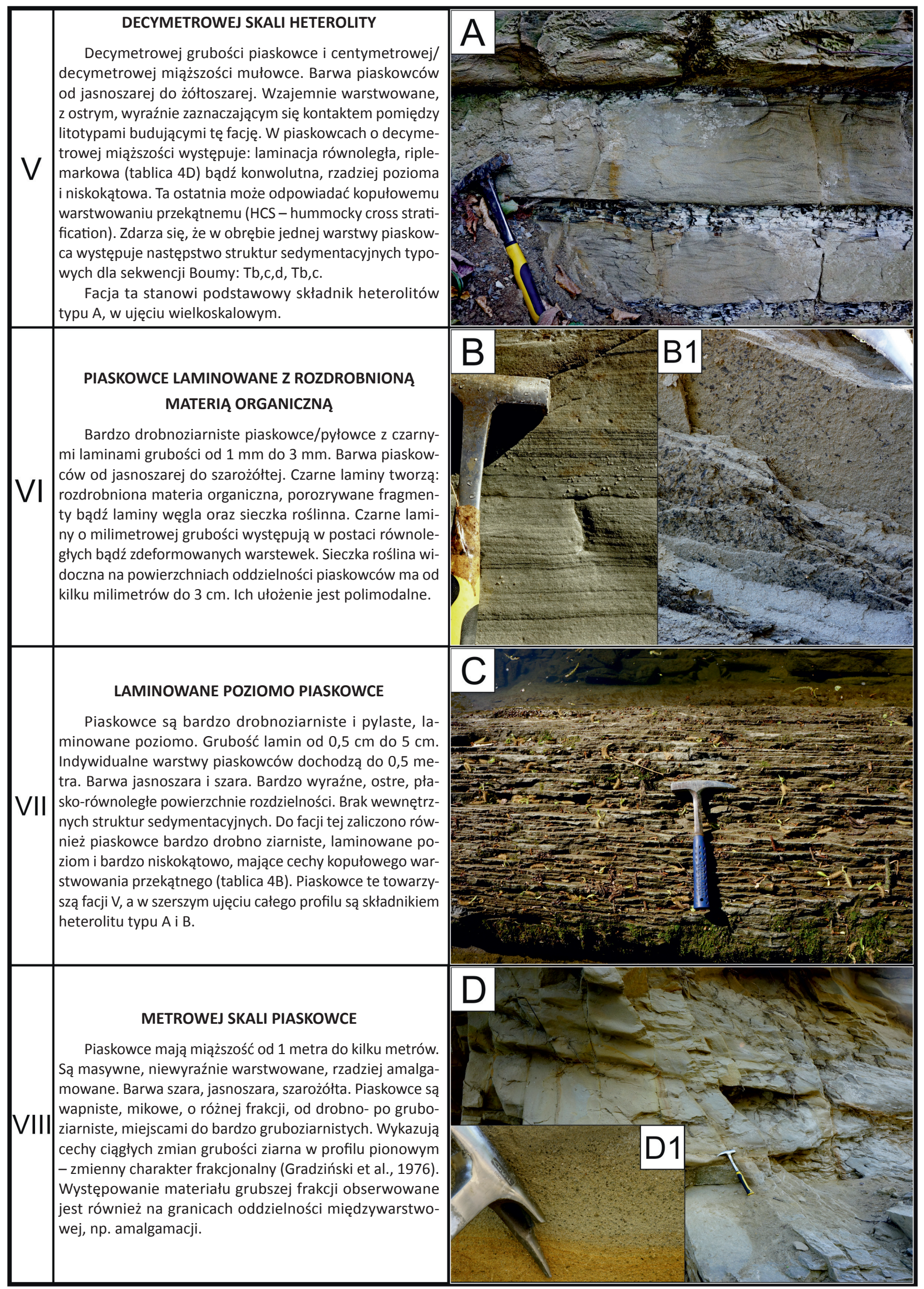


TABLICA 3

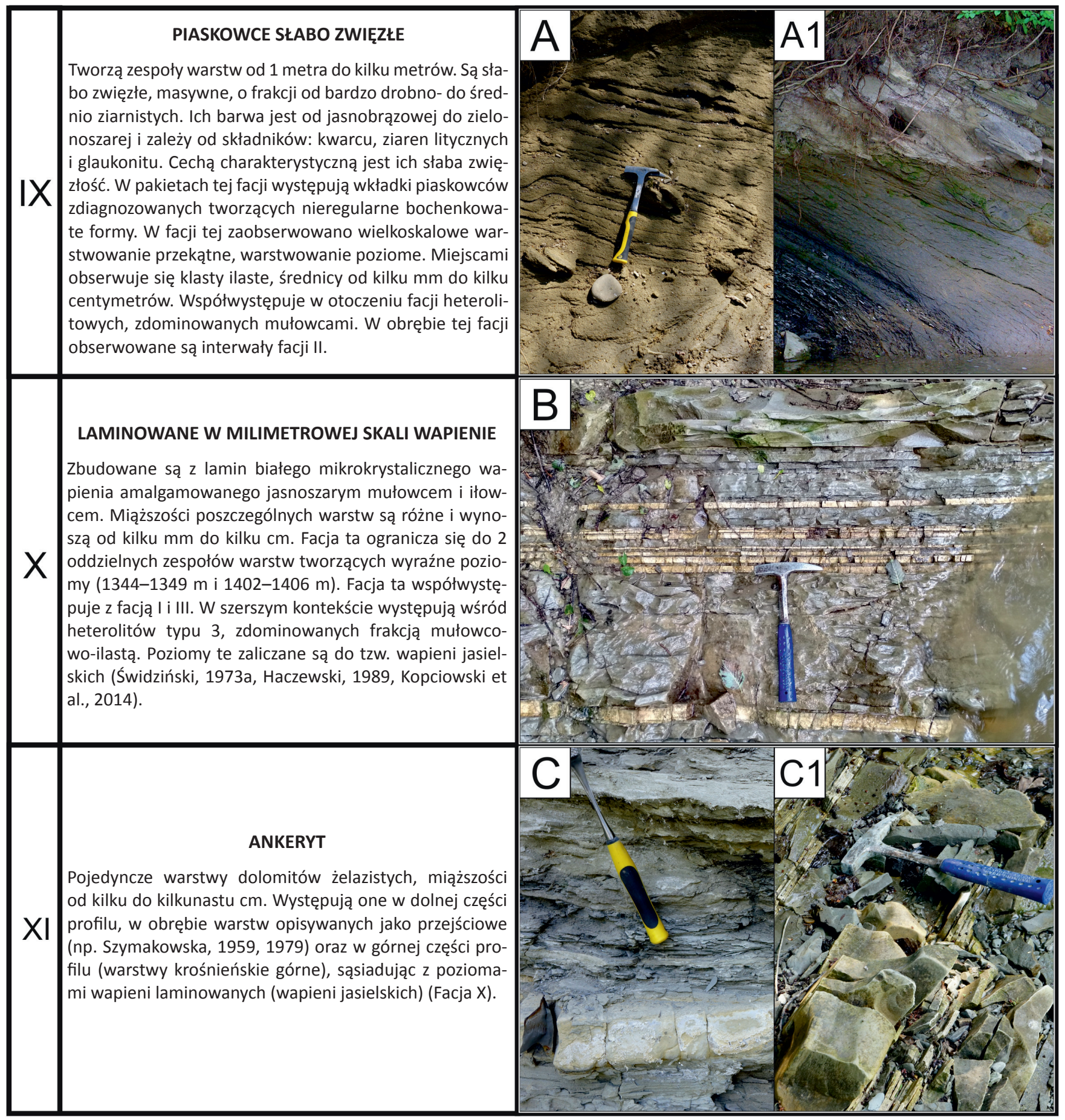

\section{OPISY DO TABLIC}

Tablica 1. Zestawienie opisów i zdjęć facji I, II, III, IV warstw krośnieńskich południowego skrzydła fałdu Gorlic

Table 1. List of descriptions and photos of facies I, II, III, IV of the Krosno Beds located on the southern limb of the Gorlice Fold

Tablica 2. Zestawienie opisów i zdjęć facji V, VI, VII, VIII warstw krośnieńskich południowego skrzydła fałdu Gorlic

Table 2. List of descriptions and photos of facies V, VI, VII, VIII of the Krosno Beds located on the southern limb of the Gorlice Fold

Tablica 3. Zestawienie opisów i zdjęć facji IX, X, XI warstw krośnieńskich południowego skrzydła fałdu Gorlic

Table 3. List of descriptions and photos of facies IX, X, XI of the Krosno Beds located on the southern limb of the Gorlice Fold

Tablica 4. Wybrane struktury sedymentacyjne warstw krośnieńskich południowego skrzydła fałdu Gorlic; A - symetryczna powierzchnia stropowa w bardzo drobnoziarnistym piaskowcu, w obrębie heterolitu typu C zbudowanego głównie z facji I i III (fot. A. Drozd); 
TABLICA 4

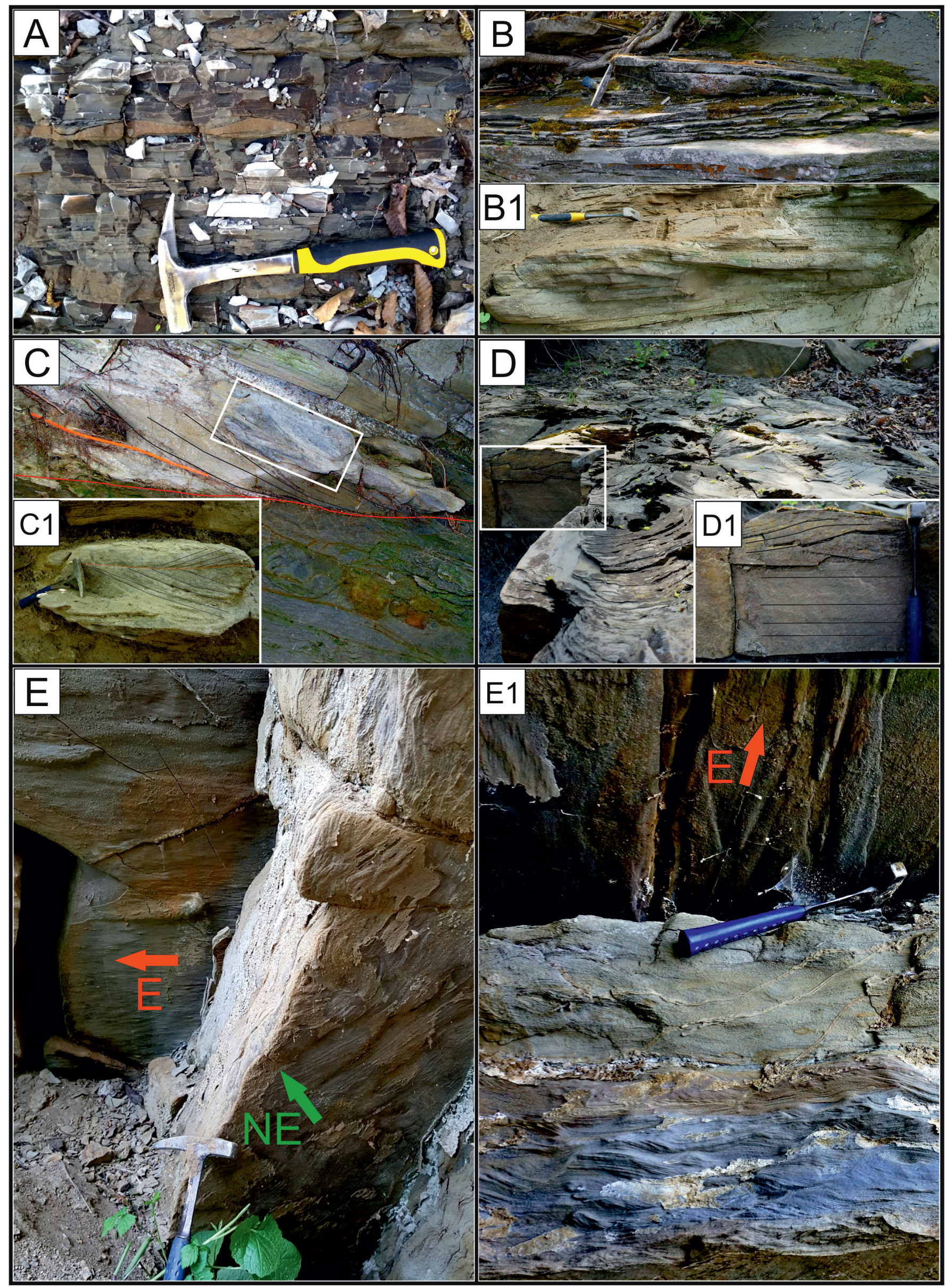




\section{— cd. s. 669 / ect. p. 669}

B - kopułowe warstwowanie przekątne w obrębie bardzo drobnoziarnistego piaskowca (facja VII) (fot. A. Drozd); B1 - kopułowe warstwowanie przekątne w obrębie bardzo drobnoziarnistego piaskowca (fot. P. Dziadzio); C, C1 - warstwowanie przekątne (rynnowe) w dużej skali w piaskowcu bardzo drobno- i drobnoziarnistym (fot. P. Dziadzio); D - laminacja sinusoidalna oraz riplemarki prądowe w stropowej części piaskowca bardzo drobnoziarnistego (facja V) (fot. A. Drozd); D1 - piaskowiec z laminacją poziomą i riplemarkową w stropie (fot. A. Drozd); E - rozbieżne kierunki transportu w spągowych częściach piaskowców facji V: kierunek wschodni zaznaczony przez hieroglify prądowe (strzałka czerwona), kierunek północno-wschodni zaznaczony przez spągowy zapis rozciągłości riplemarków wstępujących (strzałka zielona) (fot. A. Drozd); E1 - piaskowce facji V z szeregiem struktur sedymentacyjnych: hieroglify prądowe w spągowej części piaskowca bardzo drobnoziarnistego (czerwona strzałka wskazuje kierunek paleotransportu - na wschód), laminacja riplemarkowa prądowa ('środkowa część zdjęcia), laminacja riplemarkowa wstępująca (w dolnej części zdjęcia) (fot. A. Drozd)

Table 4. Selected sedimentary structures of the Krosno Beds located on the southern limb of the Gorlice Fold. A - type C heterolithic siltstone (facies I) and mudstone (facies III) overlying by very fine sandstone thin symmetric top plane (photo A. Drozd); B - hummocky cross stratification within very fine-grained sandstone bed (facies VII) (photo A. Drozd); B1 - hummocky cross stratification within very fine-grained sandstone bed (photo P. Dziadzio); C, C1 - large-scale trough cross bedding within very fine and fine-grained sandstone (photo P. Dziadzio); D - sinusoidal lamination and current ripples on the top plane of very fine-grained sandstone (facies V) (photo A. Drozd); D1 - parallel and current ripples lamination on the top plane of very fine-grained sandstone (photo A. Drozd); E - divergent transport directions visible on the bottom beddings plane of two sandstone beds (facies V): east direction marked by flute marks (red arrow), north-east direction marked by strike of the climbing ripples direction (E1) (green arrow) (photo A. Drozd); E1 - very fine-grained sandstones (facies V) with a sedimentary structures: flute marks in the bottom sandstone bed (the red arrow indicates the east direction of paleotransport), current-rippled lamination (the middle part of the photo), climbing-ripple cross-lamination (the bottom of the photo) (photo A. Drozd)

należące do facji VI (drobnoziarniste piaskowce $\mathrm{z}$ rozdrobnioną sieczką roślinną i laminami węgla) i heterolity typu B. Tego typu następstwo facji znajduje odniesienie w dzwonowatym charakterze krzywej gamma.

Granica 4 (G4) wyznaczona została w spągu piaskowców przypisanych do facji VIII. W tych piaskowcach cyklicznie pojawiają się: laminacja równoległa, riplemarkowa oraz kopułowe warstwowanie przekątne. W spągach piaskowców występują liczne hieroglify prądowe, wskazujące na kierunek paleotransportu z zachodu na wschód (tablica 4E).

Granica 5 (G5) wyznaczona została w spągu bardzo drobnoziarnistych piaskowców z zespołem struktur sedymentacyjnych takich jak: warstwowanie przekątne niskokątowe, riplemarki symetryczne oraz drobne klasty ilaste w spągowych częściach pakietów piaskowców.

Na postawie przeprowadzonej korelacji pomiędzy danymi zebranymi w terenie i danymi geofizyki otworowej można dokonać weryfikacji dotychczasowego stanu wiedzy na temat wykształcenia facjalnego warstw krośnieńskich południowego skrzydła fałdu Gorlic.

Bardzo dobrze korelującym się interwałem na profilu litologicznym, jak i geofizycznym są tzw. warstwy krośnieńskie przejściowe, występujące pomiędzy granicami G1 a G2. Mają one bardzo zbliżoną miąższość (około $150 \mathrm{~m}$ ) we wszystkich profilach. W ich obrębie występują wkładki facji II (łupków menilitowych). Ich cechą charakterystyczną jest również dominacja gruboławicowych piaskowców facji VIII, oddzielanych utworami mułowcowymi facji II i III (rys. 2A, B, C). W obrębie tego interwału występuje również heterolit typu A.

Pomiędzy granicami G2-G3 i G3-G4 interpretować można 2 cykle drobnienia ziarna ku górze, co widoczne jest w profilu terenowym i geofizycznym. W pierwszym (G2-G3) powyżej gruboławicowych piaskowców facji VIII występuje heterolit typu B z facjami III, IV, V i IX. Drugi (G3-G4) rozpoczyna się piaskowcami facji IX, powyżej których obserwuje się heterolit typu $\mathrm{C}$ z przewagą facji I, III, IV, V.

Powyżej granicy 4 (G4) profil staje się bardziej piaszczysty. Spowodowane jest to występowaniem większej ilości niewielkiej miąższości, o dużej częstotliwości warstw piaskowców facji VII i VIII. Ponad gruboławicowymi piaskowcami facji VIII często występuje heterolit typu B, zdominowany przez facje III, IV, V, VI i VII.

Powyżej granicy 5 (G5) trudno jest wyznaczyć charakterystyczne cechy umożliwiające korelację pomiędzy profilem terenowym a zapisem geofizyki wiertniczej. Aż do około $1000 \mathrm{~m}$ w profilu terenowym występuje głównie (nie licząc $100 \mathrm{~m}$ zakrytych na odcinku 830-930) heterolit typu B, który złożony jest przede wszystkim z facji III, IV, V, VI, VII.

Od $1000 \mathrm{~m}$ aż do końca opisanego profilu występuje jedynie heterolit typu C, zdominowany facją I i III, z nielicznymi bardzo cienkimi wkładkami piaskowców bardzo drobnoziarnistych (tablica 4A). Jedyną charakterystyczną facją jest facja XI - wapieni jasielskich. Niestety duża węglanowość całego profilu warstw krośnieńskich nie pozwala na identyfikację tej facji na zapisie geofizyki otworowej.

\section{Podsumowanie i wnioski}

Szczegółowe prace terenowe w obrębie południowej części jednostki śląskiej, w korycie rzeki Sękówka (pomiędzy Gorlicami a Sękową), dały podstawę do wydzielenia 


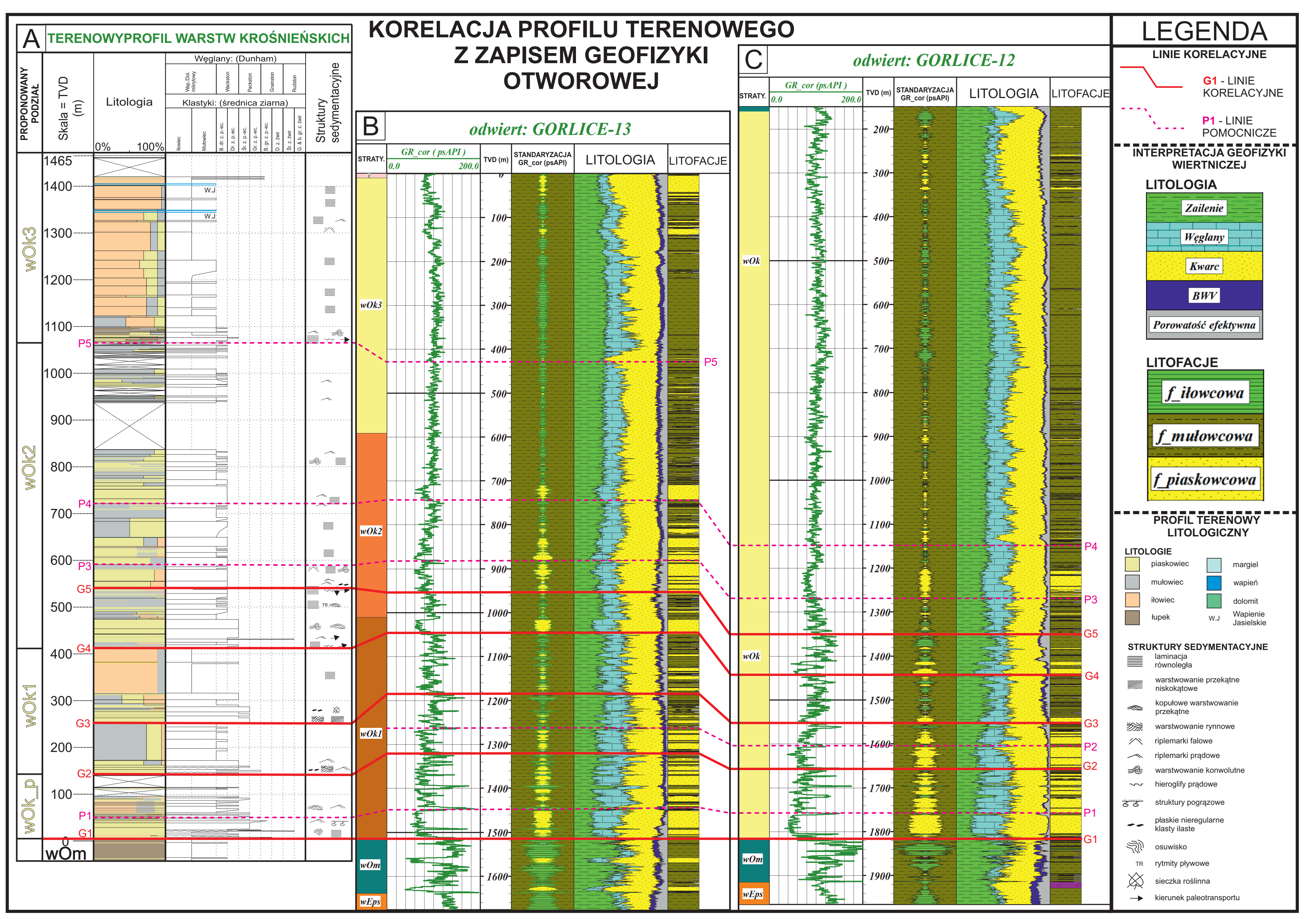

Rys. 2. Korelacja terenowego profilu litologicznego (A) z zapisem i interpretacją profilowań geofizyki otworowej z otworów Gorlice-13 (B) i Gorlice-12 (C) Fig. 2. Correlation of the field lithological profile (A) with the well logs interpretation of Gorlice-13(B) and Gorlice-12 (C) boreholes 
w profilu warstw krośnieńskich 11 facji osadowych, dla których na tym etapie badań nie przedstawiono interpretacji środowisk depozycji. Rozpoznano i udokumentowano 15 struktur sedymentacyjnych, które jednak w przyszłości można będzie wykorzystać do interpretacji genetycznych facji.

W ramach przeprowadzonej korelacji terenowego profilu litologicznego i zapisu krzywych geofizyki wiertniczej z otworów G-12 i G-13 wyznaczono 5 głównych granic korelacyjnych oraz 5 pomocniczych, nie interpretując ich genezy. Wymienione granice, z wyjątkiem P5, dało się wyznaczyć tylko w dolnej części profilu. W górnej jego części brak jest charakterystycznych cech zarówno na krzywych geofizycznych, jak i na profilu litologicznym, ponieważ warstwy krośnieńskie zdominowane są cienkowarstwowymi heterolitami typu B i C.

Przyjmując, że właściwy jest tradycyjny trójdzielny podział warstw krośnieńskich, bardziej celowe wydaje się doprecyzowanie go poprzez uwzględnienie trendów uziarnienia w dużej skali, jako fizycznego wyznacznika, niż przyjmowanie literaturowych (Szymakowska, 1979) i otworowych (Zychowicz, 1980; Zwierzyńska, 1984) (rys. 2B, C) schematów wyznaczania granic. Proponuje się podział na 3 cykle (rys. 2A - kolumna „Proponowany podział”). Pierwszy cykl (wOk_p; wOk1), obejmujący łącznie odpowiednik literaturowych warstw przejściowych (G1-G2) i krośnieńskich dolnych, można wyznaczyć pomiędzy granicami G1 a G4. Ma on wyraźny charakter drobnienia ziarna ku górze. Drugi cykl (wOk2), odpowiadający warstwom krośnieńskim środkowym, można wyznaczyć od granicy G4 do granicy pomocniczej P5 i charakteryzuje się wyraźnie większym udziałem facji mułowcowej (facja III) tworzącej heterolity typu B i C. Trzeci cykl (wOk3), będący warstwami krośnieńskimi górnymi, znajduje się powyżej granicy P5 (rys. 2A) i składa się z heterolitu typu C, który tworzą facje I i III.

W wyniku przeprowadzonych prac po raz pierwszy wykonany został tak szczegółowy terenowy profil litologiczny warstw krośnieńskich, uwzględniający dokumentację struktur i tekstur sedymentacyjnych. Jego rzeczywista miąższość została obliczona na około 1415 m, co odbiega od wartości dotychczas opisanych w literaturze (np. Szymakowska, 1979; Świdziński, 1973b). Szymakowska określa łączną miąższość warstw krośnieńskich na około $1700 \mathrm{~m}$. Opisany przez nią profil (fig. 4 w: Szymakowska, 1979) różni się także od profilu przedstawionego $\mathrm{w}$ niniejszej pracy (rys. 2A, B, C) stopniem zmienności litologicznej, która była podstawą dotychczasowego, trójdzielnego podziału warstw krośnieńskich (w obrębie fałdu Gorlic) na dolne, środkowe i górne.

Kolejną rozbieżnością jest zapiaszczenie dolnych warstw krośnieńskich, które w profilu literaturowym (fig. 4 w: Szymakowska, 1979) jest znacznie większe niż zaobserwowane przez autorów podczas prac terenowych, jak również wynikające z interpretacji profilowań geofizyki otworowej (rys. 2A, B, C). Różna jest także miąższość tzw. warstw przejściowych, którą w niniejszym opracowaniu określono na około 150 m, w porównaniu do 20-50 m według Szymakowskiej (1979). Wspólną, niepodważalną cechą jest jedynie wyraźny spadek zapiaszczenia w górę profilu.

Wyniki przeprowadzonych badań mogą stanowić podstawę do weryfikacji dotychczasowego stanu wiedzy na dużym obszarze, gdzie występują zarówno otwory wiertnicze, jak i profile terenowe. Mogą one być wykorzystywane do regionalnych interpretacji zmienności facjalnej i do interpretacji środowisk depozycji.

Artykuł powstał na podstawie pracy badawczej pt. Facje warstw krośnieńskich południowego skrzydła fałdu Gorlic, w oparciu o badania terenowe $i$ dane geofizyczne - praca INiG - PIB na zlecenie MNiSW; nr zlecenia: 0041/SG/2019, nr archiwalny: DK-4100-0041/2019.

\section{Literatura}

Cyfrowy modelu terenu, www.geoportal.gov.pl (dostęp: wrzesień 2018).

Dziadzio P., 2015. Śródmenilitowe piaskowce magdaleńskie jako przykład płytkowodnej sedymentacji deltowej w Karpatach. Nafta-Gaz, 9: 624-631.

Dziadzio P.S., Matyasik I., Garecka M., Szydło A., 2016. Lower Oligocene Menilite Beds, Polish Outer Carpathians: supposed deep-sea flysch locally reinterpreted as shelfal, based on new sedimentological, micropalaeontological and organic-geochemical data. Prace Naukowe Instytutu Nafty $i$ Gazu - Państwowego Instytutu Badawczego, 213: 1-120.

Gradziński R., Kostecka A., Radomski A., Unrug R., 1976. Sedymentologia. Wydawnictwo Geologiczne, Warszawa.

Haczewski G., 1989. Poziomy wapieni kokkolitowych w serii menilitowo-krośnieńskiej - rozróżnianie, korelacja i geneza. Annales Societatis Geologorum Poloniae, 59: 435-523.

Jankowski L., 1997. Warstwy z Gorlic - najmłodsze utwory południowej części jednostki śląskiej. Przegląd Geologiczny, 45(3): 305-308.

Jankowski L., 2007. Chaotic complexes in Gorlice region (Polish outer Carpathians). Biuletyn Państwowego Instytutu Geologicznego, 426: 27-52.

Jucha S., Kotlarczyk J., 1959. Próba ustalenia nowych poziomów korelacyjnych w warstwach krośnieńskich Karpat polskich. Acta Geol. Pol., 9(1): 55-91.

Konarski E., 1980. Wgłębna budowa karpackiej pokrywy fliszowej w rejonie gorlicko-krośnieńskim. Wydawnictwo Geologiczne, Warszawa.

Kopciowski R., Zimnal Z., Chrząstowski J., Jankowski L., Szymakowska F., 2014. Szczegółowa Mapa Geologiczna Polski 1:50 000, arkusz Gorlice. Państwowy Instytut Geologiczny, Warszawa.

Kozikowski H., 1956. Geologia płaszczowiny magurskiej i jej okien tektonicznych na południowy zachód od Gorlic. Biuletyn Instytutu Geologicznego, 110: 47-77.

Kozikowski H., Jednorowska A., 1957. Problem wieku warstw grybowskich i tzw. ,szarej kredy” okolic Gorlic. Przeglad Geologiczny, 5(3): 106-110. 
Pirson S.J., 1977. Geologic well log analysis. $2^{\text {nd }}$ ed. Gulf Publishing Company, Houston: 1-377.

Poprawa D., Nemčok J., 1989. Geological Atlas of the Outer Carpathians and Their Foreland 1:500 000. Państwowy Instytut Geologiczny, Warszawa.

Szymakowska F., 1959. Rozwój warstw krośnieńskich w niektórych obszarach Karpat Środkowych. Geological Quarterly, 3(3): 620-637.

Szymakowska F., 1979. Budowa geologiczna południowego skrzydła fałdu Gorlic między Gorlicami a Krygiem (Karpaty Środkowe). Annales Societatis Geologorum Poloniae, 85-103.

Świdziński H., 1973a. Budowa geologiczna i roponośność rejonu Szymbarku koło Gorlic. Prace Geologiczne Komitetu Nauk Geologicznych PAN, Oddziat w Krakowie, 80: 10-57.

Świdziński H., 1973b. Budowa geologiczna rejonu Ropica-Siary Górne. Prace Geologiczne Komitetu Nauk Geologicznych PAN, Oddziat w Krakowie, 80: 63-76.

Walker R.G., James N.P., 1992. Facies models: response to sea level change. St. John's, Nfld.: Geological Association of Canada. Association géologique du Canada.

Wdowiarz S., 1985. Niektóre zagadnienia budowy geologicznej oraz ropo- i gazonośności centralnego synklinorium Karpat w Polsce. Biuletyn Instytutu Geologicznego, 350: 5-52.

Zwierzyńska M., 1984. Dokumentacja wynikowa otworu badawczego Gorlice-13. CAG PIG, Warszawa.

Zychowicz K., 1980. Dokumentacja wynikowa otworu badawczego Gorlice-12. CAG PIG, Warszawa.

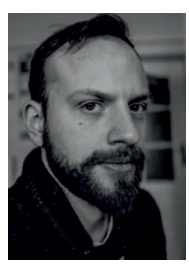

Mgr inż. Arkadiusz DROZD

Starszy specjalista badawczo-techniczny w Zakładzie Geologii i Geochemii

Instytut Nafty i Gazu - Państwowy Instytut Badawczy ul. Lubicz 25 A

31-503 Kraków

E-mail: arkadiusz.drozd@inig.pl

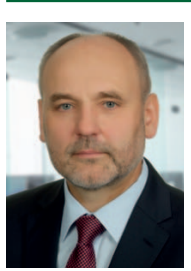

Dr Piotr S. DZIADZIO

Adiunkt w Zakładzie Geologii i Geochemii

Instytut Nafty i Gazu - Państwowy Instytut Badawczy ul. Lubicz $25 \mathrm{~A}$

31-503 Kraków

E-mail:piotr.dziadzio@inig.pl

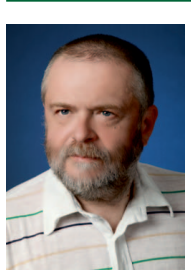

Mgr inż. Marek STADTMÜLLER

Starszy specjalista badawczo-techniczny

w Zakładzie Geologii i Geochemii

Instytut Nafty i Gazu - Państwowy Instytut Badawczy

ul. Lubicz 25 A

31-503 Kraków

E-mail: marek.stadtmuller@inig.pl

\section{OFERTA BADAWCZA ZAKŁADU} GEOLOGII I GEOCHEMII

petrofizyczne analizy laboratoryjne: gęstość, porowatość, parametry przestrzeni porowej, analizy przepuszczalności, analiza mikro i makro szczelinowatości na ptytkach cienkich i fragmentach rdzeni, petrograficzna ocena sktadu mineralnego, procesów diagenetycznych, analiza rozmieszczenia i geometrii przestrzeni porowej na podstawie ptytek cienkich, przeptywy fazowe, zwilżalność, ściśliwość;

geochemiczne analizy laboratoryjne: ocena składu macerałowego i refleksyjności witrynitu, piroliza Rock-Eval (oznaczanie zawartości TOC, wolnych weglowodorów, wegla rezydualnego), określenie potencjatu wegglowodorowego skat macierzystych, analiza elementarna węglowodorów i kerogenu (C,H,N,S, wspótczynniki H/C i O/C), skład chemiczny i izotopowy gazów, badania gazu wolnego (desorbowanego) i resztkowego, badania ekstrahowalnej substancji organicznej oraz analiza składu grupowego, analiza biomarkerów GC-MS (frakcja nasycona i aromatyczna, analiza GC-FID frakcji nasyconej), korelacja rop ze skatami macierzystymi:

modelowanie geologiczne 3D ztóż i obszarów poszukiwawczych: interpretacja danych geofizyki wiertniczej (petrofizyczna, geochemiczna, geomechaniczna, szczelinowatości), modelowanie strukturalne, facjalne i parametrów petrofizycznych z wykorzystaniem danych otworowych i sejsmicznych, modelowanie geomechaniczne, obliczanie zasobów na bazie modeli 3D ztóż wraz z analizą niepewności:

sedymentologia dla geologii naftowej: analizy sedymentologiczne rdzeni wiertniczych, analizy środowisk depozycyjnych facji osadowych, stratygrafia sekwencji, analizy sedymentologiczne odstonięć powierzchniowych oraz ich integracja z danymi otworowymi (rdzenie, pomiary geofizyki otworowej) i sejsmicznymi, dystrybucja rozkładu facji w basenach sedymentacyjnych, predykcja występowania ciał zbiornikowych i ich orientacja przestrzenna w skali basenu sedymentacyjnego;

modelowanie 1D/2D/3D systemów naftowych: odtwarzanie ewolucji strukturalnej, termicznej i parametrycznej basenu sedymentacyjnego w skali czasu geologicznego, rekonstrukcja czasu i przebiegu procesów generowania i ekspulsji węglowodorów, modelowanie dróg migracji węglowodorów i miejsc ich akumulacji, ocena zasobów prognostycznych, analiza niepewności, ranking obiektów poszukiwawczych;

zintegrowana platforma: Petrel, PetroMod, Techlog, Interactive Petrophysics, ProGeo, Petrel Reservoir Geomechanics (Visage).

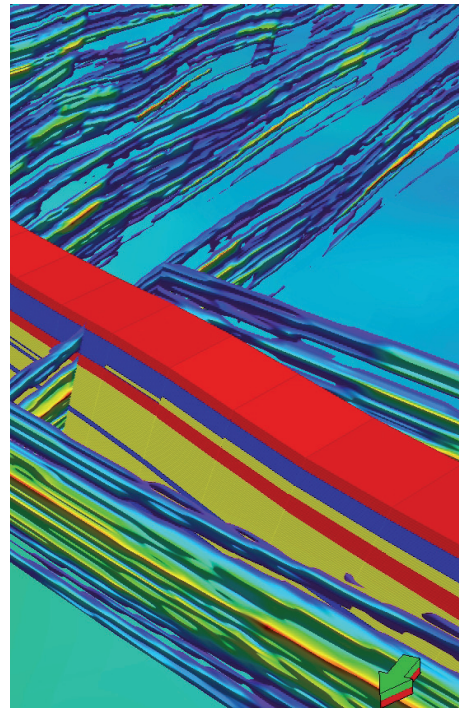

INSTYTUT NAFTY I GAZU

- Państwowy Instytut Badawczy

Kierownik: dr inż. Grzegorz Leśniak Adres: ul. Lubicz 25 A, 31-503 Kraków

Telefon: 126177687 Faks: 124303885 E- mail: grzegorz.lesniak@inig.pl 